\title{
YOUNG PEOPLE UP TO 24 YEARS ON THE LABOUR MARKET IN A SMALL SLOVAK TOWN
}

\author{
Daniel Markovič \\ Catholic University in Ružomberok, Slovakia \\ Viktor Tomlák \\ Catholic University in Ružomberok, Slovakia \\ Soňa Šrobárová \\ Catholic University in Ružomberok, Slovakia \\ Zuzana Gejdošová \\ Catholic University in Ružomberok, Slovakia
}

\begin{abstract}
Social pedagogy offers a wide multidisciplinary range to prevent and tackle youth unemployment. In this paper, we want to broaden the knowledge for social pedagogues in the areas of young people in the labour market and youth unemployment. The aim of the research is to identify the experience of respondents in the labour market in the district of Ruzomberok. It is a district in Slovakia far from the capital and regional centres. Most of the district's inhabitants live in villages, fewer inhabitants in a town of Ružomberok. We conducted a questionnaire survey of 100 respondents. There are 50 young people up to 24 years old, who are currently active in the labour market. Furthermore, there are persons unemployed, registered at the Office of Labour, Social Affairs and Family in Ružomberok, with an age limit of up to 24 years, representing the same number of 50 respondents. We explored the social context; we set two hypotheses: There is a statistically significant difference in the status of the labour market with respect to the respondents' residence. There is a statistically significant difference in the status of the labour market relative to the gender of respondents. To verify the hypotheses, we used the Chi-Square-2 variable test. The hypotheses were not confirmed.
\end{abstract}

Keywords: labour market, unemployment, young people.

\section{Introduction}

When the economy started to slow in several European countries in 2019, the interest of the professional public also focused on the related topic of unemployment. Young people are among the vulnerable groups in the labour market because of their lack of work experience and their unemployment issues have not been eliminated even during the economic boom. The cities with the best opportunities in the labour market are economic centres or capital cities. In this 
paper, we are interested in young people who do not want or cannot move and remain in a region with a more difficult situation.

In this paper, we want to broaden the knowledge for social pedagogues in the areas of young people in the labour market and youth unemployment. Social pedagogy has a preventive function; its aim is to prepare young people to enter the labour market so that they do not become unemployed. The paper informs social pedagogues what methods of job search young people who are successful in the labour market used and gives them an overview of the opinions of young people whether the labour office can find them a job. The aim of the research is to identify the experience of respondents in the labour market in the district of Ruzomberok. It is a district in Slovakia far from the capital and regional centres. Most of the district's inhabitants live in villages, fewer inhabitants in a town of Ružomberok.

\section{Literature review}

The situation of young people in the labour market, dramatically affected by the consequences of the economic crisis that started in 2008, remains a major challenge for the European Union. In the post-crisis period, unemployment among young people under 24 was historically highest in the Member States of the European Union, up to $40 \%$ in some countries and Slovakia was no exception. The situation has been improving since 2013 when the youth unemployment rate has reached its highest level in the EU and in most EU Member States (Eurostat, 2019; Kontaktný výbor, 2018).

A very important factor for a better understanding of youth unemployment is the social factor. Adolescence is a period in a person's life where orientation at the level of professional, civic and social life is crucial. The most important thing for the young generation is to find employment in the labour market. It is this period for a young person that is the stage of gaining a professional identity, in other words, the young person chooses a profession and begins his/her professional training (Buchtová, 2002). At the end of adolescence, young people who do not continue their studies at the university enter the labour market.

The EU youth unemployment rate (aged 15-24) was 18.7\% in 2016, 4.9 percentage points (pp) below the maximum level achieved in 2013 (23.6\%). In 2018, the youth unemployment rate was $15.2 \%$ in the EU, $14.9 \%$ in Slovakia. Despite these signs of improvement, the youth unemployment rate remains particularly high. Moreover, Youth unemployment rates are generally much higher, even double or more than double, than unemployment rates for all ages (Eurostat, 2019).

Considering the structure of Slovakia's economy and regional disparities, young people from the Žilina region, the Banská Bystrica region, the Košice 
region and finally from the Prešov region have the biggest problem. At the same time, the conditions for the financial evaluation of work are disproportionately lower in these regions. Young people from these regions are forced to migrate abroad and at the same time, they migrate within Slovakia, which causes the extinction of municipalities (Reš, 2017).

A young person starts her/his career at a new job usually in a lower position. The social role of a beginner has usually a low social status with low-wage (Markovič, 2018). "After graduation, young people are often deprived of the opportunity to put their knowledge and skills into practice. Employers consider young people that they lack broader professional knowledge, which they usually prefer over profound and narrow knowledge acquired during their studies. This makes it difficult for new graduates to enter the labour market” (Kuchař, 2007). High youth unemployment has a long-term negative impact on the economy. If young people are not able to find employment in the labour market after completing their studies, whether secondary or university, they are forced to either travel abroad for work or remain unemployed in Slovakia. In the first case, if it is a temporary event, the pension earned abroad or part of it is likely to be consumed in the home country, which is more beneficial to the economy. On the other hand, those who remain unemployed will have difficulty acquiring their own housing and to become independent. They will remain dependent on state transfers or will work illegally. Another negative aspect of high unemployment is the motivation to go abroad permanently. They are often educated people who do not have a high enough rating in our market (Červenka, 2013).

Labour market policy is characterized as a system of support for citizens in their integration into the labour market. It is a set of forms, activities, measures and instruments used for the desired direction of the labour market and for solving of (un)employment of persons. These instruments serve not only to help the registered unemployed people, but the legislation also includes measures to encourage all persons to be able to help themselves in finding employment (Laštúvková, 2005).

The Ministry of Labour, Social Affairs and Family of the Slovak Republic deal with the development of labour market policy in Slovakia. It determines the priorities and objectives of labour market policy (Gejdošová, 2012). These objectives also reflect the intentions of economic and social policy, specified in the government's policy statement and other documents approved by the National Council of the Slovak Republic. The legislative framework for the implementation of labour market measures is created by Act no. 5/2004 Coll. on Employment Services and on amendments to certain acts.

The basic objectives of an active labour market policy are to help those at risk of unemployment while helping already unemployed people to find employment in the labour market before they become unemployed in the long 
term. The basic services of an active labour market policy (regulated by the Employment Services Act) are a mediation of suitable employment, education and training for the labour market, job creation support and professional advisory/counselling services. According to their objectives, active labour market policy instruments can be divided into instruments that increase employability, instruments that increase employment and instruments that support the retention of existing jobs (Laštúvková, 2005).

\section{Methodology}

The aim of the research is to identify the experience of respondents in the labour market in the district of Ruzomberok. It is a district in Slovakia far from the capital and regional centres. Most of the district's inhabitants live in villages, fewer inhabitants in a town of Ružomberok. We conducted a questionnaire survey of 100 respondents. There are 50 young people up to 24 years old, who are currently active in the labour market. Furthermore, there are persons unemployed, registered at the Office of Labour, Social Affairs and Family in Ružomberok, with an age limit of up to 24 years, representing the same number of 50 respondents. We explored the social context; we set two hypotheses: H1 There is a statistically significant difference in the status of the labour market with respect to the respondents' residence. $\mathrm{H} 2$ There is a statistically significant difference in the status of the labour market relative to the gender of respondents. We chose the quantitative research strategy, author questionnaire method, which allowed us to collect and analyse the obtained data in a relatively short time, and enable their required statistical processing. The questionnaire of own design was anonymous. The research was conducted during February 2019.

The data collection was followed by the data processing phase. It was carried out in the SPSS statistical program, where we processed the individual answers of the respondents graphically and transparently through statistical methods. To verify the hypotheses, we used the Chi-Square-2 variable test.

In the final phase of the research, we focused on evaluating the results of the research, based on which we made individual recommendations for practice.

\section{Sample Description}

Our research sample consisted of 100 respondents. Half of the respondents were young people up to the age of 24 , who were on the labour market in the district of Ružomberok. The remaining 50 respondents were persons up to 24 years of age registered as unemployed at the Office of Labour, Social Affairs and Family in Ružomberok (OLSAF). Of the total number of 100 respondents, 52 were men, accounting for $52 \%$ and 48 women, representing $48 \%$. 
Table no. 1 shows statistical data related to the age of respondents. The average age of respondents involved in our research is 21.2 years. The table also shows that most respondents were 23 years of age. The oldest respondent was 24 years old, while the youngest respondent was 18 years old.

Table 1 The age of respondents

\begin{tabular}{|c|c|}
\hline Average & 21,2 \\
\hline Median & 22 \\
\hline Modus & 23 \\
\hline Minimum & 18 \\
\hline Maximum & 24 \\
\hline
\end{tabular}

$54 \%$ of respondents live in the village. The remaining $46 \%$ of the respondents identified the town as their residence. It mirrors the real situation in the district of Ruzomberok.

\section{Research results}

The status of respondents in the labour market. More than half, namely $57 \%$ of respondents identified their status in the labour market as unemployed. This number is high in terms of the number of respondents, but this was assumed due to the distribution of fifty questionnaires to the OLSAF clients. The second largest group consisted of employed respondents representing 16\%. These were followed by $15 \%$ of students with employment. Nine $\%$ of respondents registered the option of a student without a job. At least, only 3\% of respondents rated entrepreneurship as their status in the labour market. The structure of our respondents does not reflect the real situation on the labour market in the district, as half of our research sample is unemployed - registered at the labour office.

Opinions of respondents with work experience on ways of getting a job. The aim of the next question in our questionnaire was to find out the respondents' opinions on how to get their job. This question was addressed only to respondents with experience in the labour market. 77 respondents answered this question. Figure 1 shows that most, namely 32 (41.56\%) respondents used the help of friends and acquaintances to get a job. 20 (25.97\%) respondents stated their own initiative as the second most common way of getting a job. OLSAF helped to $11(14.29 \%)$ respondents. These were followed by job portals, to which seven (9.09\%) responded. Four (5.19\%) respondents stated that they got a job thanks to work agencies. Our respondents were least helped by social networks to get a job. Only three (3.90\%) respondents indicated this option. 


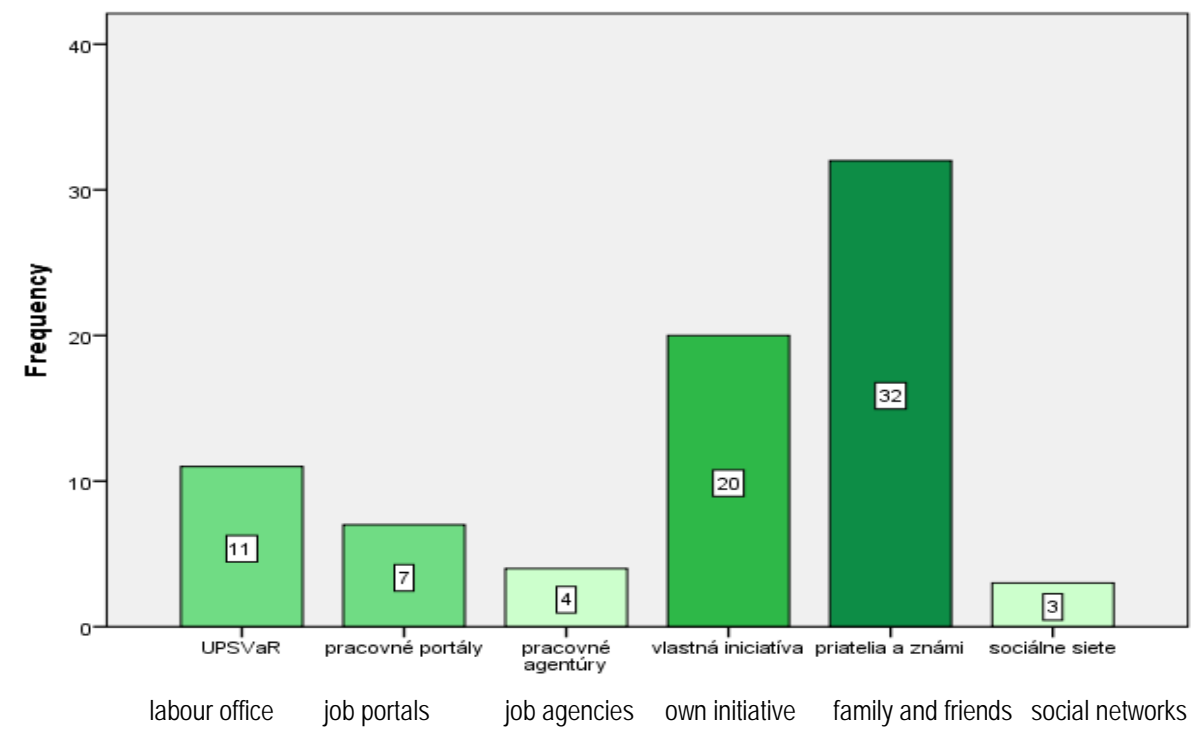

Figure 1 Opinions of respondents with work experience on ways of getting a job

Opinions of respondents without work experience on the best choice of job search. Through the following question, we wanted to find out the respondents' views on the best way to find a job. This question was answered only by respondents who had any experience with the labour market. For the purposes of our research, we did not consider the practice during the study as an experience in the labour market. A total of 23 respondents answered the question. Figure 2 shows that respondents considered the help of friends and acquaintances to be the best choice for finding a job. 15 (65.22\%) respondents indicated this answer. 3 respondents stated their own initiative. 2 (8.70\%) respondents considered the help of the OLSAF and job portals the best choice for job search. Only one of the respondents identified social networks as the best choice when looking for a job.

Young people who have succeeded in the labour market have used similar ways of looking for a job compared to the ideas of their unemployed colleagues. The most common response in both groups was the help of family and acquaintances, followed by a self-initiative. The unemployed did not mention employment agencies. 


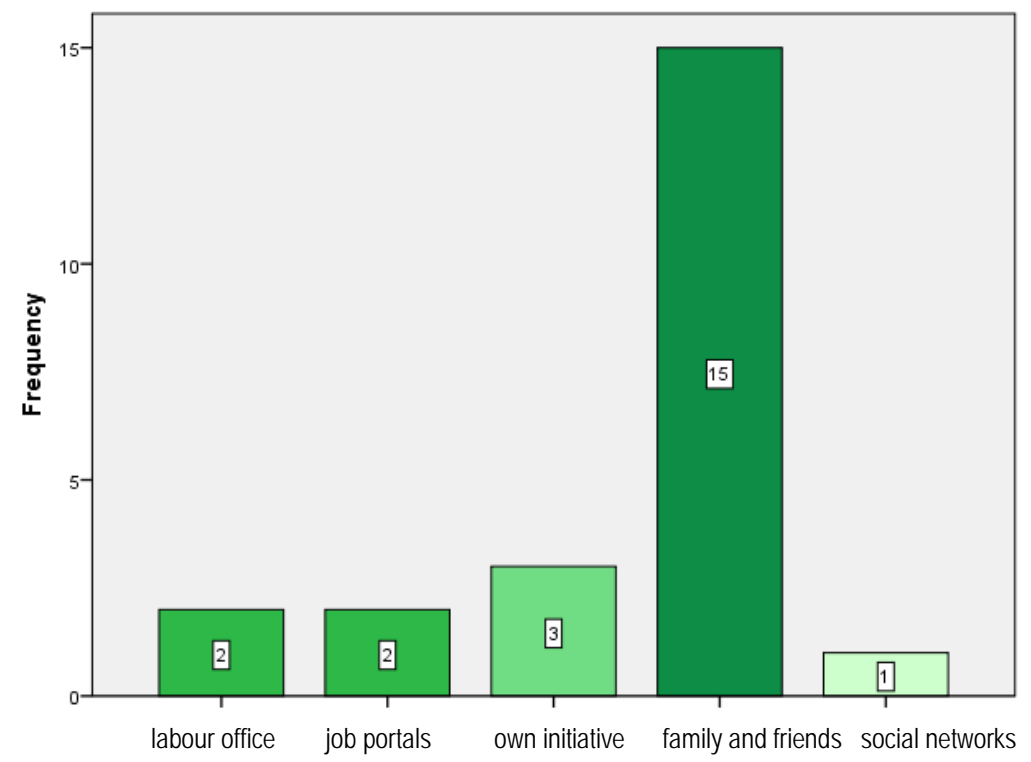

Figure 2 Opinions of respondents without work experience on the best way of job search

Opinions of respondents on the mediation of suitable employment by the OLSAF. In this question, we surveyed respondents' views on OLSAF's ability to mediate appropriate employment based on their requirements. From graph 3, it is evident that more than half, exactly $60 \%$ of respondents are unable to evaluate OLSAF's activities and capabilities in this area. 23\% of respondents are of the opinion that OLSAF is not able to mediate adequate employment. In contrast, $17 \%$ of respondents believe that OLSAF is able to mediate employment based on their requirements.

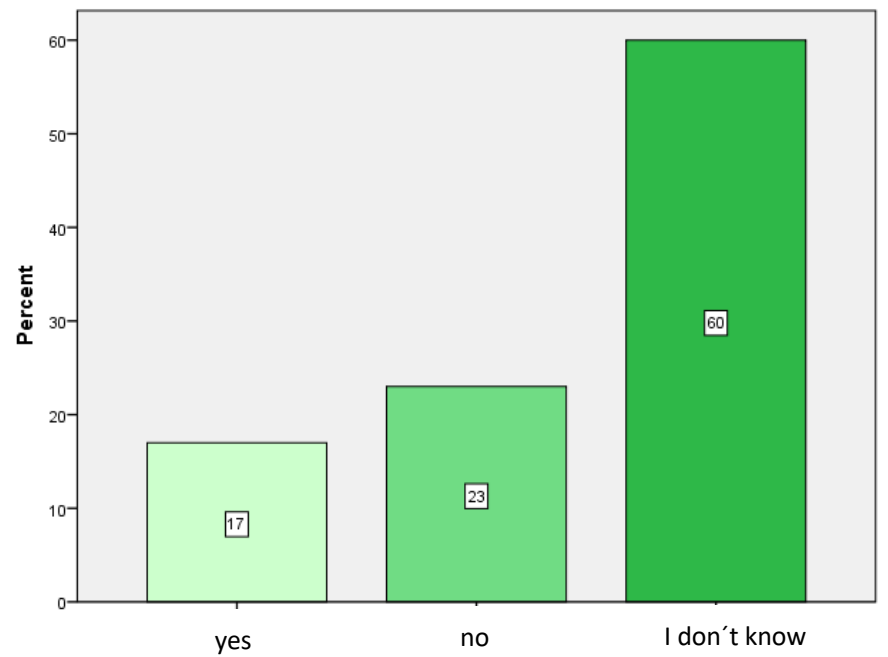

Figure 3 Opinions of respondents on the mediation of suitable employment by the OLSAF 
The verification of hypotheses. To verify the hypotheses, we used the Chi-Square-2 variable test, which is used to test the frequencies of a combination of two or more nominal variables. Using the given test, we find out whether the distribution of frequencies of variable $\mathrm{x}$ depends on or does not depend on variable y.

Our first hypothesis was $\mathrm{H} 1$ There is a statistically significant difference in the status of the labour market with respect to the respondents' residence. The hypothesis was verified by two questions. Figure 19 shows that there is a difference in the status of the labour market with respect to the residence of individual respondents. To verify whether this difference is statistically significant, we used the aforementioned Chi-Square test with 2 variables.

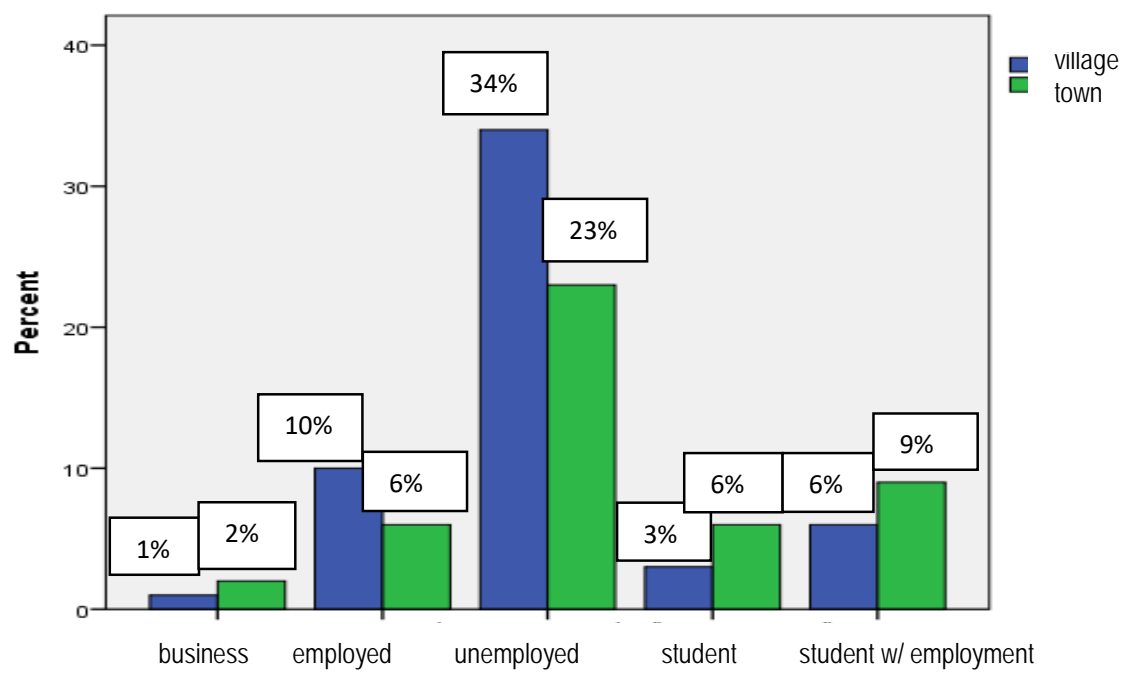

Figure 4 Difference in labour market status with respect to respondents' residence

From table 3 we conclude that the first hypothesis was not confirmed because $\mathrm{p}=0.349>0.05$, and thus we can reject the alternative hypothesis of the existence of the difference and accept the null hypothesis that there is no statistically significant difference in the status of the labour market with respect to residence individual respondents.

Table 2 Pivot table - working status, residence

Residence * Working status Crosstabulation

Count

\begin{tabular}{|ll|c|c|c|c|c|c|}
\hline & \multicolumn{6}{|c|}{ Working status } & Total \\
\cline { 3 - 7 } & Business & Employed & Unemployed & $\begin{array}{c}\text { Student } \\
\text { without job }\end{array}$ & $\begin{array}{c}\text { Student } \\
\text { with job }\end{array}$ & \\
\hline \multirow{2}{*}{ Residence } & village & 1 & 10 & 34 & 3 & 6 & 54 \\
\multirow{2}{*}{ Total } & city & 2 & 6 & 23 & 6 & 9 & 46 \\
\hline
\end{tabular}


SOCIETY. INTEGRATION. EDUCATION

Proceedings of the International Scientific Conference. Volume IV, May $22^{\text {th }}-23^{\text {th }}, 2020.290-300$

Table 3 Scoreboard Chi-Square - 2 test variables - comparison of labour market status with respect to residence

Chi-Square Tests

\begin{tabular}{|l|c|c|c|}
\hline & Value & Df & Asymp. Sig. (2-sided) \\
\hline Pearson Chi-Square & $4,445^{\mathrm{a}}$ & 4 &, 349 \\
Likelihood Ratio & 4,469 & 4 &, 346 \\
Linear-by-Linear & 1,617 & 1 &, 203 \\
Association & 100 & & \\
N of Valid Cases & & \\
\hline
\end{tabular}

a. 4 cells $(40,0 \%)$ have expected count less than 5 . The minimum expected count is 1,38 .

Our second hypothesis was H2 There is a statistically significant difference in the status of the labour market relative to the gender of respondents. The hypothesis was verified by two questions, graph 5 shows that there is a difference in the status of the labour market with respect to the sex of individual respondents. We also used the Chi-Square test with 2 variables to verify whether this difference was statistically significant.

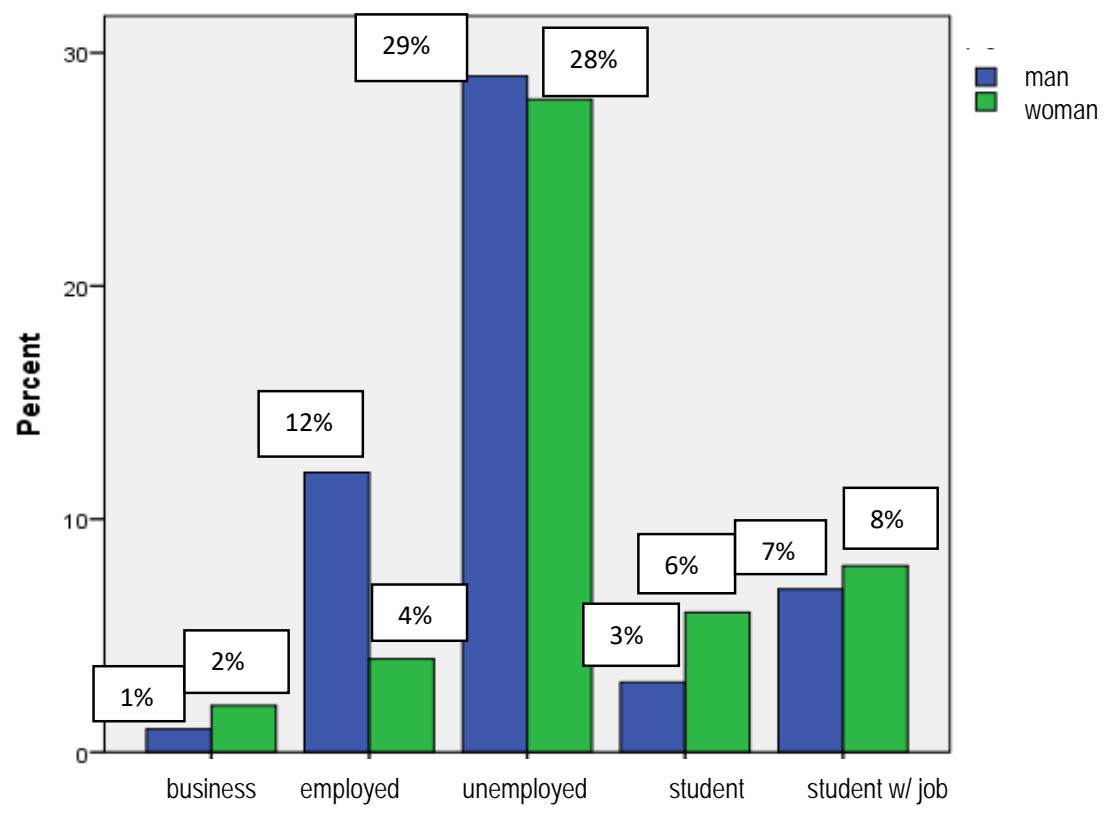

Figure 5 Difference in labour market status with respect to respondents' gender

The value of $\mathrm{p}=0.261>0.05$, and thus we can reject the alternative hypothesis of the existence of the difference and accept the null hypothesis, which implies that there is no statistically significant difference in the status of the labour market with respect to respondents' sex. 
Table 4 Pivot table - working status, gender

Gender * Working status Crosstabulation

Count

\begin{tabular}{|ll|c|c|c|c|c|c|}
\hline & \multicolumn{6}{|c|}{ Working status } & Total \\
\cline { 3 - 8 } & Business & Employed & Unemployed & $\begin{array}{c}\text { Student without } \\
\text { job }\end{array}$ & $\begin{array}{c}\text { Student with } \\
\text { job }\end{array}$ & \\
\hline \multirow{2}{*}{ Gender } & Man & 1 & 12 & 29 & 3 & 7 & 52 \\
Total & Woman & 2 & 4 & 28 & 6 & 8 & 48 \\
& 3 & 16 & 57 & 9 & 15 & 100 \\
\hline
\end{tabular}

Table 5 Chi-Square Scoreboard - 2 test variables - comparison of labour market status with respect to gender

\section{Chi-Square Tests}

\begin{tabular}{|l|c|c|c|}
\hline & Value & Df & Asymp. Sig. (2-sided) \\
\hline Pearson Chi-Square & $5,266^{\mathrm{a}}$ & 4 &, 261 \\
Likelihood Ratio & 5,469 & 4 &, 242 \\
Linear-by-Linear & 1,437 & 1 &, 231 \\
Association & 100 & & \\
N of Valid Cases & 100 & \\
\hline
\end{tabular}

a. 4 cells $(40,0 \%)$ have expected count less than 5 . The minimum expected count is 1,44 .

\section{Conclusions}

We found out by testing hypotheses that there is no statistically significant difference in the status of the labour market with respect to respondents' sex and what is more, there is no statistically significant difference in the status of the labour market with respect to residence of respondents. Most young people in our research do not know whether labour offices are able to find a suitable job for them. Young people who have succeeded in the labour market have used similar ways of looking for a job compared to the ideas of their unemployed colleagues. The most common response in both groups was the help of family and acquaintances, followed by a self-initiative.

In addition to social policy and labour office initiatives, it is necessary to address young people in the labour market as well as at the micro level; social policy can offer a wide range of instruments

\section{Acknowledgements}

This paper was supported by the Grant Agency of the Faculty of Education CU GAPF 2019/2020. 
SOCIETY. INTEGRATION. EDUCATION

Proceedings of the International Scientific Conference. Volume IV, May $22^{\text {th }}-23^{\text {th }}, 2020.290-300$

\section{References}

Buchtová, B. et al. (2002). Nezaměstnanost'. Psychologický, ekonomický a sociální problém. Praha: Grada Publishing.

Council of the European Union. (2012). Odporúčanie rady Európskej únie z 20. decembra 2012 o potvrdzovaní neformálneho vzdelávania a informálneho učenia sa. Retrieved from http://eurlex.europa.eu/LexUriServ/LexUriServ.do?uri=OJ:C:2012:398:0001:0005:SK: PDF

Červenka, S. (2013). Vývoj nezamestnanosti mladých l’udí na Slovensku. Bratislava: Iness. Retrieved from https://www.iness.sk/sk/stranka/8126-Vyvoj-nezamestnanosti-mladychludi-na-Slovensku

Eurostat. (2019). Unemployment statistics. Retrieved from https://ec.europa.eu/eurostat/ statistics-explained/index.php?title=Unemployment_statistics\#Youth_unemployment

Gejdošová, Z. (2012). Sociálne zabezpečenie v systéme verejnej správy na Slovensku. Ružomberok: Verbum.

Kontaktný výbor najvyšších kontrolných inštitúcií Európskej únie. (2018). Nezamestnanost' mladých l'udí a integrácia mladých l'udí na trhu práce. Luxemburg: Úrad pre vydávanie publikácií Európskej únie. DOI: https://doi.org/10.2865/389436

Kuchař, P. (2007). Trh práce - sociologická analýza. Praha: Karolinum.

Laštúvková, L. (2005). Aktívna politika trhu práce. Retrieved from https://www.epi.sk/ odborny-clanok/Aktivna-politika-trhu-prace.htm

Markovič, D. (2018). The youth in the European labour market. Is it lost generation?. SHS Web of Conferences. DOI: https://doi.org/10.1051/shsconf/20185101001

Reš, D. et al. (2017) Správa o mládeži 2018 - Situačná analýza kvality života mladých l'udí v Slovenskej republike. Bratislava: Ministerstvo školstva, vedy, výskumu a športu SR. 